\title{
Increasing Productivity In CPO Production Using The Objective Matrix (OMAX) Method
}

\author{
Defi Irwansyah $^{1 *}$, Cut Ita Erliana ${ }^{1}$, Fadlisyah $^{2}$, Mutammimul Ula ${ }^{3}$, Mahlil Fahrozi ${ }^{1}$, Rofiq Harun ${ }^{4}$ \\ ${ }^{1}$ Department of Industrial Engineering, Faculty of Engineering, Universitas Malikussaleh, Aceh, Indonesia \\ ${ }^{2}$ Department of Informatics, Faculty of Engineering, Universitas Malikussaleh, Aceh, Indonesia \\ ${ }^{3}$ Department of Information System, Faculty of Engineering, Universitas Malikussaleh, Aceh, Indonesia \\ ${ }^{4}$ Department of Informatics, Universitas Ichsan Gorontalo, Indonesia \\ *Corresponding author E-mail: defiirwansyah@unimal.ac.id
}

Manuscript received 30 Nov 2021; revised 3 Dec 2021; accepted 10 Jan 2022. Date of publication 10 April 2022

\begin{abstract}
PT. Ika Bina Agro Wisesa (IBAS) is a company that produces products in the form of crude oil or CPO (Crude Palm Oil). The company sets a minimum production target of FFB that must be processed to reach 30 tons in one boiling with a minimum production target of 600 tons/day. The company is required to increase productivity. The problem so far is that the company has never measured the productivity of the production process, which will then affect the achievement of production targets. Measurement of productivity is critical because the measursizeoductivity can determine whether the company meets productivity targets for production or not. Therefore, it is necessary to measure productivity to assess the value of productivity and efforts to increase productivity in CPO production and how to increase productivity in CPO production and efforts to increase productivity using the Objective Matrix (OMAX) method at PT. Ika Bina Agro Wisesa. Analysis of productivity using the OMAX method, ratio 3 (labor productivity) and ratio 4 (machine productivity) has a very high percentage of poor performance, which means that ratio and 4 have an insufficient level of productivity. Unlike the case with the achievement of productivity ratio 1 (productivity of raw materials) and ratio 2 (productivity of working hours) wh, ich shows a low percentage of poor performance, which means that the productivity level of ratio one and ratio 2 has a better productivity level than ratio three and ratio 4 Analysis The results of the productivity index in the company decreased and increased for each month, in November it experienced a decrease of -79.49, while in December it experienced a significant increase in the amount of 595.02 and January at 69.98. in February decreased to -23.63. Furthermore, productivity in March - September 2021 was unstable, with an increase and dropped for July, a decrease of -0.64 and, a slight increase in August of 0.28.
\end{abstract}

Keywords: Productivity, CPO, Objective Matrix Method.

\section{Introduction}

PT. Ika Bina Agro Wisesa is one of the companies in Guha Uleue Village, Kuta Makmur District, North Aceh Regency, Aceh Province that produces products in crude oil or CPO (Crude Palm Oil). PT. Ika Bina Agro Wisesa (IBAS) runs its production activities for 24 hours every day (non-stop), where the working hours are divided into three work shifts. Furthermore, PT. Ika Bina Agro Wisesa is required to increase productivity. Productivity measurement is critical because productivity measurement can determine whether the company meets the productivity target for production.

Productivity measurement is critical because productivity measurement can determine whether the company meets the productivity target for production [1]. Analysis of Performance Measurement System With Integrated Performance Measurement Systems Method In Pt. X, the best performance measurement in this study. This study aims to determine the needs of company stakeholders (Stakeholder Requirement) and improve and enhance company performance [2]. Computer technology is critical in conducting business and market interactions in busirn companies [3]. Research results determined total and partial levels with the Objective Matrix model. Namely shoNamelyhat the value of productivity fluctuates and the importance of improvements that can be made by optimizing each element of productivity [4]. In further research, the main products of palm oil milling, namely Crude Palm Oil and Kernels, which have been analyzed, have not achieved the production target,t which causes fluctuations in profits that are not optimal in the use of production resources [5]. The decline in the index is influenced by an increase in prices from outside the company [6].

Therefore, it is necessary to measure productivity to determine the value of productivity and efforts to increase productivity in CPO production at PT. Ika Bina Agro WisesaThe utilization of resources pla a vitaltant role in the production process. Consider the availability of resources to determine production Most manufacturing [7]. Furthermore, to gain profits, companies need to increase resource utilization by determining the level of productivity [8]. 
One method of measuring productivity that can solve this problem is the Objective Matrix (OMAX). This method combines productivity criteria into an integrated form and relates to each other. Thus, this model can identify factors influencing and affecting more negligiblesing productivity. This method is expected to provide an overview that can be used as a certaispecificmark in the measure. It can be seen how effective the production process has been to increase output and how efficient the input sources are in increasing productivity.

\section{Literature Review}

\subsection{The Role and Importance of Productivity}

Productivity in a company is used to analyze and see production efficient efficiency how determinedly the company has inputs (resources) in producing the targeted output. [9]. The productivity company'sproductivitt to win essentialness-competitive you and productivithaveve, any input factors to prodproductiontput which will ultimately provide an added value to the company [10]. The importance of a New Model in Attendance Monitoring System by Using RFID Technology to increase company productivity [11] [12].

An increase in productivity also results in an immediate standard of liv under an equal distribution of productivity gains corresponding to labor input. At the national level, increased productivity complements raising living standards or making equality of life. [13].

\subsection{Productivity}

Productivity is defined as the $r$ between inputs and outputs of a production system. This relationship is often more commonly expressed as the output ratio to information. [14]. Measworkt of productivity that has benefits for a company are as follows: (1) The strategy to increase company productivity can be determined based on the level of prprod activity gap between the planned productivity level and the measured productivity level; (2) Planning for future productivity level targets can be changed again based on information on measuring productivity levels; (3) Resource planning will become more effective and efficient through productivity measurement, both in short-term planning and long-term planning; (4) Measurement of productivity will create competitive actions in the form of continuous productivity improvement efforts. [15]. Productivity is a concept related to the results (amount of goods and services produced) and resources (labor, raw materials, capital, energy, etc.) used to make these goods. [16], defines productivity as the ability to create.

\subsection{Methods in Productivity Measurement}

There are several productivity measurement models that are often used in productivity measurement, namely: (1) Productivity Evaluation Tree (PET) Model This PET model is one method of doing short-term productivity planning using a productivity evaluation tree; (2) The OMAX Objective Matrix (OMAX) model combines productivity criteria into an integrated form and relates to each other. The form and structure of this productivity model consist of productivity criteria, achievement scores, matrix items, scores, weights, scores, and performance indicators [17]. Furthermore, the Objective Matrix (OMAX) can measure work units on a small scale and for the entire company. But the resdoingf measuring the units' performance teams be linked addictively to represent the performance of the parent units. A calculated processor of the related groups must be carried out [18]. CRM performance evaluation in the performance objective matrix can measure the value of satisfaction in determining how much customer satisfaction the objective matrix method calculates the importance [19].

\subsection{Method Objective Matrix (OMAX)}

Objective Matrix is a partial productivity measurement system developed to monitor productivity in a company in each section only with productivity criteria the accordance of that network section he measurement of productivity using the OMAX model is a comb several success measures or productivity criteria that have been weighted according to the degree of importance of each step or cribar the company [20]. Objective Matrix is a performance measurement method using achievement indicators and a weighting procedure to obtain a total productivity index.

The arrangement of this model is in the form of a matrix, namely a table whose cells are arranged according to columns and rows so that they can be read from top to bottom and from left to right. This matrix arrangement will make it easier to operate. The composition of the Objective Matrix model consists of several parts, namely the following.[20]:

1. Productivity Criteria

The criteria that describe the productivity measure are in the uppermost group of this matrix. As for calculating the value of the ratio can use the formula:

$$
\begin{aligned}
\text { Ratio }(1) & =\frac{\text { Product output quantity }}{\text { Use of main raw materials }} \\
\text { Ratio }(2) & =\frac{\text { Product output quantity }}{\text { Working hours }} \\
\text { Ratio }(3) & =\frac{\text { Absen }}{\text { Available working hours }} \\
& =\frac{\text { Employee attendance (person) } \mathrm{x} \text { working hours }}{\text { Available working hours }} \\
\text { Ratio }(4) & =\frac{\text { Machine working hours }}{\text { Mache }}
\end{aligned}
$$
Machine breakdown hours

2. Set end goals and scores

3. Weight

The formula used in calculating the percentage weight value is:

Weight percentage $=\underline{\sum \text { weight of each ratio }} \times 100 \%$

information:

$$
\sum \text { whole weight ratio }
$$

$\sum$ every ratio $=$ total weight of each ratio

$\sum$ every ratio $=$ total weight of each ratio

4. Productivity Value

The value of the achievement that was successfully obtained for each criterion in a certain period was obtained by multiplying the score on a particular criterion by the criterion's weight. The formula used to calculate the productivity value, namely: 
Productivity value $=$ actual score $\mathrm{x}$ weight

5. Level of Achievement

After some time, measurements are made to monitor the magnitude of the achievement of performance for each criterion.

6. Achievement Indicators

The magnitude of achievement indicators determines the increase in productivity. The formula used to calculate the achievement indicator value is:

Achievement indicators $=$ NP Ratio $1+\ldots .+$ NP to-n

Information: $\mathrm{NP}=$ Productivity Value

\subsection{Calculation of Productivity Index (IP)}

The company's productivity level is measured based on the results of the above calculations. The productivity growth pattern is analyzed to determine the company's development during the measurement period. Analysis of the percentage change in the productivity index for each measurement period. The formula for calculating the productivity index is by:

Indeks Productivity $=\underline{\mathrm{IP}_{\mathrm{i}}-\mathrm{IP}_{\mathrm{i}-1}} \times 100 \%$

Information:

$$
\mathrm{IP}_{\mathrm{i}-1}
$$

$\mathrm{IP}_{\mathrm{i}}=$ Initial achievement indicator value

$\mathrm{IP}_{\mathrm{i}-1}=$ Initial achievement indicator value

\section{Method}

\subsection{Stages of Research Implementation}

This research was conducted at PT. Ika Bina Agro Wisesa is located in Guha Uleue Village, Kuta Makmur Subdistrict, North Aceh Regency, Aceh Province.

\subsection{Data Collection Techniques}

Data collection techniques used in this study include:

1. Primary data

Primary data is the data obtained through observation and direct interviews with interested parties in PT. Ika Bina Agro Wisesa on how perus-ahaan productivity.

2. Secondary data consisting of raw material data, production data, number of team member absences, machine breakdown hours, regular machine working hours, and journals related to productivity analysis are used to support research in solving problems.

\subsection{Data Processing}

After collecting data, perform data processing by calculating the ratio based on the measured criteria. Determine the measurement criteria to focus more on the main categories of determining productivity criteria, namely:

1. Efficiency criteria show how resources are used company is used as sparingly as possible. These criteria include:

The ratio I: balance ratio between the amount of product output produced and the raw materials used.

The ratio compares the number of product outputs produced and hours worked.

2. Inferential criteria, namely criteria that can indirectly

affect productivity, these criteria include:

Ratio III: is a comparison between the number of absenteeism of workers with working hours.

Ratio IV: is a comparison between the number of machine-hours worked with machine break down.

\subsection{Formation of OMAX Matrix}

The values in the formation of the omax matrix are the initial stage value, the final target value, the lowest value, and the weighted value of each ratio. The following is a table of OMAX matrix formation from November 2020 - September 2021.

\subsection{Calculation of productivity index}

After obtaining the achievement indicator values each month during the measurement period, then the achievement indicator values are used to calculate the company's productivity index every month during the measured period. The results of the calculation of the productivity index for each period describe the decrease and increase in productivity achieved by the company.

\section{Results and Discussion}

\subsection{CPO Production Data Analysis}

The data obtained for CPO production in one year can be seen in Table 1 below:

Table 1. Data needed in CPO Productivity Measurement

\begin{tabular}{|c|c|c|c|c|c|c|c|c|c|}
\hline Years & Month & $\begin{array}{l}\text { raw Ingre- } \\
\text { dient } \\
\text { (Ton) }\end{array}$ & $\begin{array}{l}\text { output } \\
\text { (Ton) }\end{array}$ & $\begin{array}{l}\text { Number of } \\
\text { Workers } \\
\text { (Person) }\end{array}$ & $\begin{array}{l}\text { Work- } \\
\text { ing } \\
\text { Hours } \\
\text { (Hour) }\end{array}$ & $\begin{array}{c}\text { available working } \\
\text { hours } \\
\text { (Hour) }\end{array}$ & $\begin{array}{l}\text { Team mem- } \\
\text { ber Absences } \\
\quad \text { (person) }\end{array}$ & $\begin{array}{l}\text { Machine break- } \\
\text { down (Hour) }\end{array}$ & $\begin{array}{c}\text { machine } \\
\text { working } \\
\text { hours } \\
\text { (Hour) }\end{array}$ \\
\hline \multirow{3}{*}{2020} & Oct & 17211 & 2822 & 119 & 24 & 624 & 3 & 3 & 624 \\
\hline & Nov & 15060 & 2248 & 119 & 24 & 624 & 3 & 2 & 624 \\
\hline & Des & 15114 & 2553 & 119 & 24 & 624 & 4 & 0 & 624 \\
\hline
\end{tabular}




\begin{tabular}{|c|c|c|c|c|c|c|c|c|c|}
\hline \multirow{9}{*}{2021} & Jan & 17174 & 2821 & 119 & 24 & 624 & 1 & 0 & 624 \\
\hline & Feb & 17610 & 2849 & 121 & 24 & 624 & 3 & 1 & 624 \\
\hline & Mar & 18065 & 2910 & 121 & 24 & 624 & 2 & 0 & 624 \\
\hline & Apr & 18827 & 3021 & 121 & 24 & 624 & 4 & 0 & 624 \\
\hline & May & 18248 & 2963 & 121 & 24 & 624 & 2 & 1 & 624 \\
\hline & Jun & 16786 & 2793 & 121 & 24 & 624 & 1 & 2 & 624 \\
\hline & Jul & 15394 & 2621 & 123 & 24 & 624 & 1 & 1 & 624 \\
\hline & Agents & 16177 & 2720 & 123 & 24 & 624 & 2 & 0 & 624 \\
\hline & Sep & 16299 & 2740 & 123 & 24 & 624 & 1 & 1 & 624 \\
\hline
\end{tabular}

Source: Secondary Data

\subsection{Standard value and the ratio value}

The measurement of the standard value is to determine the value of the initial stage, where the target matrix will be placed at the third level. To determine the value of the initial step is to average the value of the ratio in each period. The following is a recapitulation of the calculation results of the ratio value based on the calculaanalysesa predetermined formula.

Table 2. Ratio value recapitulation

\begin{tabular}{ccccc}
\hline Month & Ratio 1 & Ratio 2 & Ratio 3 & Ratio 4 \\
\hline Oct & 0.16 & 4.52 & 0.12 & 208.00 \\
\hline Nov & 0.15 & 3.60 & 0.12 & 312.00 \\
\hline Des & 0.17 & 4.09 & 0.15 & 0.00 \\
\hline Jan & 0.16 & 4.52 & 0.04 & 0.00 \\
\hline Feb & 0.16 & 4.57 & 0.12 & 0.00 \\
\hline Mar & 0.16 & 4.66 & 0.08 & 0.00 \\
\hline Apr & 0.16 & 4.84 & 0.15 & 0.00 \\
\hline May & 0.16 & 4.75 & 0.08 & 624.00 \\
\hline Jun & 0.17 & 4.48 & 0.04 & 312.00 \\
\hline Jul & 0.17 & 4.20 & 0.04 & 624.00 \\
\hline Agts & 0.17 & 4.36 & 0.08 & 0.00 \\
\hline Sep & 0.17 & 4.39 & 0.04 & 624.00 \\
\hline Average & 0.16 & 4.42 & 0.09 & 225.33 \\
\hline Sout Da & & & &
\end{tabular}

Source: Data Processing Results

\subsection{OMAX Matrix Formation}

The values in the formation of the omax matrix are the initial stage value, the final target value, the lowest value, and the weighted value of each ratio. The following is a table of OMAX matrix formation from July 2021 - September 2021.

Table 3. Objective matrix of PT. Ika Bina Agro Wisesa September 2021

\begin{tabular}{|c|c|c|c|c|c|c|}
\hline Criteria & \multicolumn{2}{|c|}{ Efficiency } & \multicolumn{2}{|c|}{ Inference } & \multirow{3}{*}{ Skor } & \\
\hline Ratio-Ratio & Ratio 1 & Ratio 2 & Ratio 3 & Ratio 4 & & \\
\hline Actual Value & 0.15 & 3.60 & 0.12 & 312.00 & & Information \\
\hline & 0,216 & 5,33 & 0,041 & 90,16 & 10 & Excellent \\
\hline & 0,208 & 5,2 & 0,048 & 109,47 & 9 & \\
\hline & 0,2 & 5,07 & 0,055 & 128,78 & 8 & \\
\hline & 0,192 & 4,94 & 0,062 & 148,09 & 7 & Good \\
\hline & 0,184 & 4,81 & 0,069 & 167,4 & 6 & \\
\hline & 0,176 & 4,68 & 0,076 & 186,71 & 5 & \\
\hline & 0,168 & 4,55 & 0,083 & 206,02 & 4 & medium \\
\hline & 0,16 & 4,42 & 0,09 & 225,33 & 3 & \\
\hline & 0,152 & 4,29 & 0,097 & 244,64 & 2 & Bad \\
\hline & 0,144 & 4,16 & 0,104 & 263,95 & 1 & Bad \\
\hline & 0,136 & 4,03 & 0,111 & 283,26 & 0 & Very bad \\
\hline Score Actual & 2 & 0 & 0 & 0 & & \\
\hline Bobot & 27,78 & 25 & 22,22 & 25 & & \\
\hline $\begin{array}{l}\text { Performance } \\
\text { Value }\end{array}$ & 55,56 & 0,00 & 0,00 & 0,00 & & \\
\hline
\end{tabular}

Source: Data Processing Results

\subsection{Calculation of Achievement Indicators}

The calculation of achievement indicators is carried out to determine the achievement of each month during the measurement period. The following are the results of analyzation of achievement indicators: 
Table 4. Achievement Indicator Results

\begin{tabular}{llllll}
\hline Month & Ratio 1 & Ratio 2 & Ratio 3 & Ratio 4 & Achievement Indicators \\
\hline Oct & 84,43 & 100 & 0 & 100 & 284,43 \\
\hline Nov & 56,56 & 0 & 0 & 0 & 56,56 \\
\hline Des & 112,12 & 25 & 0 & 250 & 387,12 \\
\hline Jan & 84,44 & 100 & 223,2 & 250 & 657,64 \\
\hline Feb & 84,34 & 100 & 66,66 & 250 & 501 \\
\hline Mar & 84,46 & 125 & 88,88 & 250 & 548,34 \\
\hline Apr & 84,34 & 150 & 0 & 250 & 484,34 \\
\hline May & 84,44 & 125 & 88,88 & 0 & 298,32 \\
\hline Jun & 138,9 & 75 & 222,2 & 0 & 436,1 \\
\hline Jul & 112,56 & 100 & 222,2 & 0 & 434,76 \\
\hline Agts & 112,16 & 75 & 88,88 & 250 & 526,04 \\
\hline Sep & 112,58 & 75 & 222,22 & 0 & 409,8 \\
\hline
\end{tabular}

Source: Data Processing Results

A graph of the change of the index from month to month can be seen in Figure 1 below:

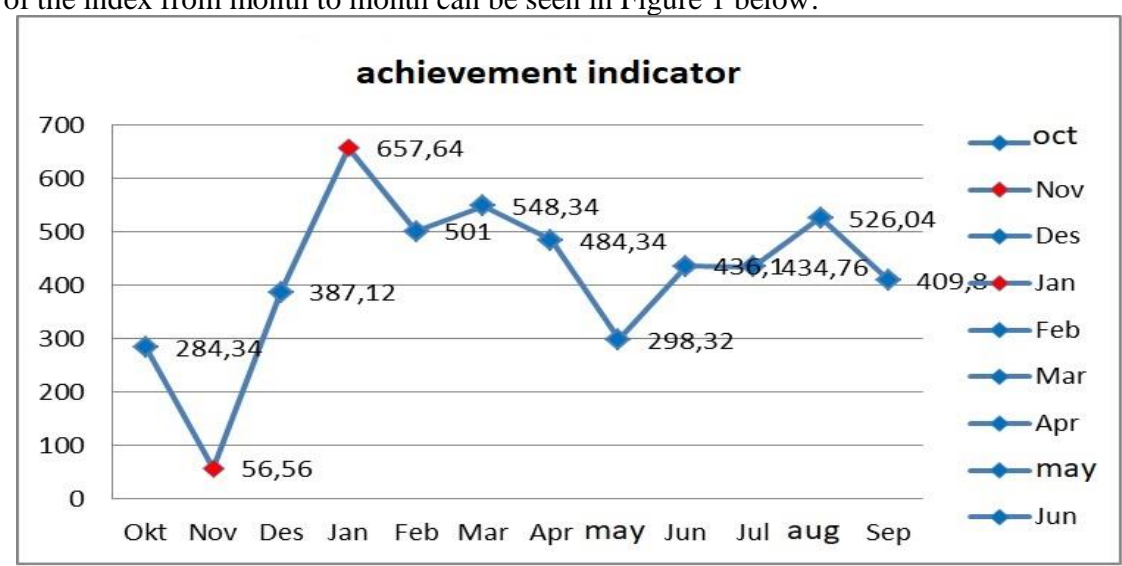

Fig 1. Performance Index Graph

\subsection{Productivity Indicator Calculation}

The calculation of productivity indicators is carried out to determine the achievement of each month during the measurement period. The following are the results of the analysis of achievement indicators:

Table 5. Productivity Indicator Results

\begin{tabular}{cc}
\hline Month & Productivity Index \\
\hline Oct & 0 \\
\hline Nov & $-79,49$ \\
\hline Des & 595,02 \\
\hline Jan & 69,98 \\
\hline Feb & $-23,63$ \\
\hline Mar & 9,54 \\
\hline Apr & $-12,77$ \\
\hline May & $-38,51$ \\
\hline Jun & 46,73 \\
\hline Jul & $-0,64$ \\
\hline Agts & 0,28 \\
\hline Sep & $-22,29$ \\
\hline
\end{tabular}

The graph of the change of the index from month to month can be seen in Figure 2 below : 


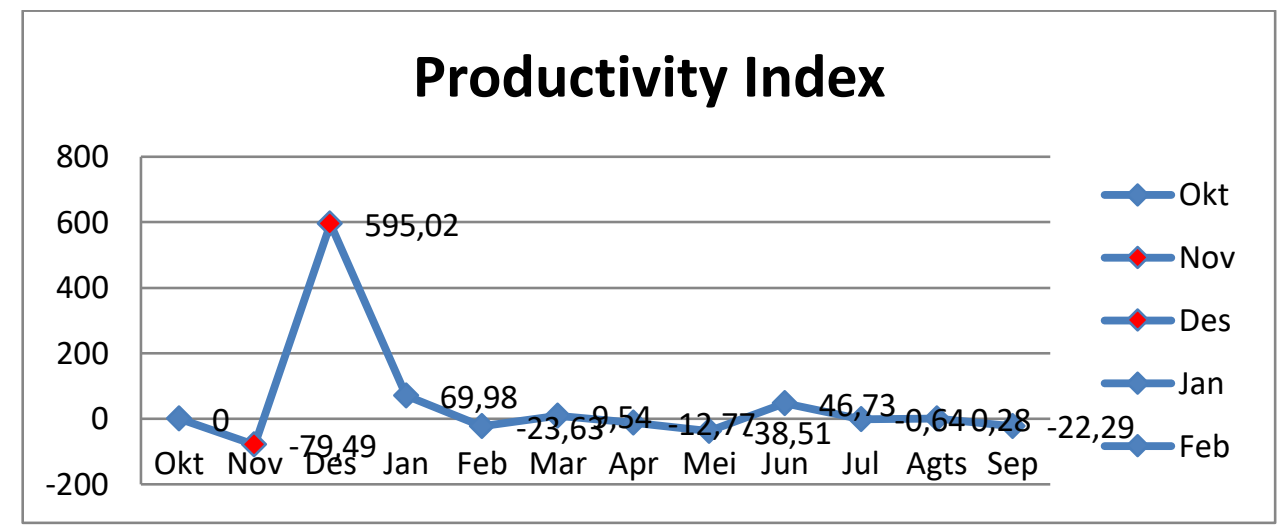

Fig 2. Performance Index Graph

\subsection{Productivity Results Analysis}

The company's productivity level is to analyze the productivity growth pattern so that the company's development can be known during the measurement period.

1. Ratio 1

In ratio 1, the output produced based on the available raw materials is one level of productivity that is classified as good; good quality raw materials support this to produce good quality output as well training for workers on the characteristics of good oil palm fruit and supervise during sorting of oil palm fruit so that the quality of raw materials remains good.

2. Ratio 2

While the ratio 2 is a comparison between the output produced and the working hours of employees. In this ratio 2, the productivity level of the company's production time is quite good. The production target set at the company is 30 tons per hour, and the company can produce more than the set target.

3. Ratio 3

Ratio 3 compares the number of team members' absences and the available working hours of employees. This ratio 3 has a low level of productivity; this is due to the working hours that have been set with the number of existing employees, requiring the company to produce raw materials based on the targets that have been set. However, the reduced number of employees (absence) affects the resulting output. The reduction in working hours caused by a shortage of employees (lack) hurts the company.

4. Ratio 4

Ratio 4 describes machines' performance in companies with poor productivity levels. This is caused by the breakdown/time of engine breakdown, thus disrupting the $\mathrm{CPO}$ production process.

\section{Conclusion}

The results of the calculation of the productivity index for each period describe the decline and increase in productivity achieved by the company; It is seen that every month there is an unstable change in productivity, in September 2020, the Productivity of PT. Ika Bina Agro Wisesa experienced a decrease in September 2021 by $-79.49 \%$ and experienced a relatively high increase in the following month, namely December, by $595.02 \%$. In the next month PT. Inka Bina Agro Wisesa experienced a decrease in productivity in February 2021 to $-23.63 \%$. Furthermore, the productivity from March to September 2021 is PT's productivity. Inka Bina Agro Wisesa is unstable; there are ups and downs.

\section{References}

[1] N. Dedi, "Pengukuran Produktvitas Untuk Mengidentifikasi Pemborosan Sumberdaya Produksi Menggunakan Metode Objective Matrix (OMAX) PT.," in Skripsi. Fakultas Teknik Universitas Tanjung Pura 6, 6th ed., Tanjung Pura, 2012.

[2] I. Alda, T., Siregar, K., "Analisis Sistem Pengukuran Kinerja Dengan Metode Integrated Performance Measurement Systems Pada Pt. X.," J. Tek. Ind. USU, vol. 2, no. 1, 2013.

[3] W. Ula, M., \& Fuadi, "A method for evaluating information security governance (ISG) components in a banking environment," $J$. Phys. Conf. Ser., vol. Vol. 812, p. 012031, 2017.

[4] W. Yosan, I. R. B., Kholil, I. M., \& Soraya, "Increasing Productivity With Objective Matrix Method Case Study on Building Maintenance Management Pio Pt. Xxx.,” Int. Semin. Ind. Eng. Manag, vol. 9, 2018.

[5] V. Lestari, F., Nuari, I., \& Devani, "American Productivity Center Method for Measuring Productivity in Palm Oil Milling Industry.," Int. Conf. Ind. Eng. Eng. Manag., pp. 754-757, 2018.

[6] D. Irwansyah, "Measurement of Study Productivity and Evaluation Analysis by using the American Productivity Center (APC) Model at a Palm Oil Factory (Pks PT. Syaukath Sejahtera).," Proc. MICoMS 2017. Emerald Publ. Limited., 2017.

[7] F. Pargar, "Resource optimization techniques in scheduling: applications to production and maintenance systems," 2017.

[8] D. O. Fakorede, A. I. Babatunde, and A. Ovat, "Productivity Increase by Optimum Utilization of Machines and Manpower Energy," Int. J. Eng. Res. Dev., vol. 10, no. 5, pp. 11-24, 2014.

[9] T. H. S. U. Becker, Huselid, Linking People, Strategy and performance, Havard Business Scholl Pres. Boston. 2001.

[10] Pramestari D, "Penentuan Kriteria Perbaikan Produktivitas Pada Suatu Departemen Kerja Dengan Menggunakan Metode Objective Matrix (OMAX)," IKRA-ITH Teknol. J. Sains Teknol., vol. 2, no. 2, pp. 9-19, 2018.

[11] R. Ula, M., Pratama, A., Asbar, Y., Fuadi, W., Fajri, R., \& Hardi, “A New Model of The Student Attendance Monitoring System Using RFID Technology,” J. Phys. Conf. Ser., vol. 1807 No. 1, p. 012026, 2021.

[12] D. Abdullah, "Perancangan Sistem Informasi Pelayanan Kapal," J. Ilm. Teknol. Inf. Terap., 2015.

[13] M. Sinungan, Produktivitas Apa Dan Bagaimana, 2nd ed. Jakarta: Bumi Aksara, 2008.

[14] L. Syarifuddin, S., \& Yani, “Analisis Produktivitas Perusahaan Pada UD. Karya Jaya,” Ind. Eng. J., vol. 3, no. $2,2014$.

[15] V. Gaspersz, Manajemen produktivitas total. Jakarta: Gramedia Pustaka Utama, 2000.

[16] R. B. H. J, Manajemen Operasi, 7th ed. Jakarta: Salemba 4, 2006. 
[17] Y. Silalahi, L. A., Rispianda, R., \& Yuniar, "USULAN STRATEGI PENINGKATAN PRODUKTIVITAS BERDASARKAN HASIL ANALISIS PENGUKURAN OBJECTIVE MATRIX (OMAX) PADA DEPARTEMEN PRODUKSI TRANSFORMER,” REKA Integr., vol. 1, no. 1, p. 138, 2017, doi: 10.25077/JOSI.V14.N1.P138-155.2015.

[18] rini setiowati, "ANALISIS PENGUKURAN PRODUKTIVITAS DEPARTEMEN PRODUKSI DENGAN METODE OBJECTIVE MATRIX (OMAX) PADA CV. JAYA MANDIRI,” Fakt. Exacta, vol. 10, no. 3, pp. 199-209, 2017.

[19] M. Rumapea, H., Prakqusa, M., Rumapea, Y. Y. P., Larosa, F. G. N., \& Yohanna, "Customer Relationship Management by Using Objective Matrix Method to Survey Customer Satisfac-tion.,” Int. Conf. Comput. Sci. Inf. Technol., pp. 1-4, 2019.

[20] Y. Avianda, D., Yuniati, Y., \& Yuniar, "Strategi Peningkatan Produktivitas di Lantai Produksi Menggunakan Metode Objective Matrix," Reka Integr., vol. 1, no. 4, 2013. 